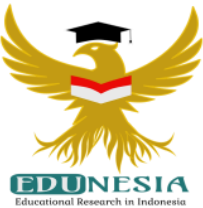

\title{
The Effect of Using Gadgets on The Level of Learning and Spirituality of Students During the Covid-19 Pandemic
}

\author{
Nur Zaytun Hasanah'; Istiqomah'; Kurniawan Dwi Saputra ${ }^{3}$ \\ 1,2,3 Islamic Education, Universitas Islam Indonesia, Indonesia \\ ${ }^{1}$ Corresponding Email: 18422098@students.uii.ac.id, Phone Number: 0822 xxxx xxxx
}

\author{
Article History: \\ Received: Dec 24, 2021 \\ Revised: Jan 02, 2022 \\ Accepted: Jan 05, 2022 \\ Online First: Jan 08, 2022
}

\section{Keywords:}

The influence of gadgets,

Learning rate,

Student Spirituality Level.

\section{Kata Kunci:}

Pengaruh Gadget,

Tingkat Belajar,

Tingkat Spiritualitas Siswa.

\section{How to cite:}

Hasanah, N.Z., Istiqomah, I., \& Saputra. K.D. (2022). The Effect of Using Gadgets on The Level of Learning and Spirituality of Students During the Covid-19 Pandemic Edunesia: Jurnal Ilmiah Pendidikan, 3 (1): 66-77.

This is an open access article under the $C C$-BY-NC-ND license
Abstract: Talking about education is certainly closely related to the generation of students. If we look at the current state of education, especially the quality that exists within students, it is very concerning. Cellphones that should be used for learning in schools are now only limited to playing games. Not a few students want to read textbooks, because they are busy reading chats from their girlfriends. Not even a few studens go to the mosque to perform Dhuha prayers and Fardhu prayers because they are busy tik-tokan. Generations of students are starting to spend a lot of time in front of gadgets. The generation that Allah says in the Qur'an as the Khoiru Ummah, is now a rare thing to see.The purpose of this study was to interpret the influence of gadgets on the level of learning and spirituality of students during the covid-19 pandemi. This research is a type of qualitative research with a qualitative descriptive research approach. Data collection techniques used are observation methods, documentation methods and interview methods. The data analysis technique used is Milles, Huberman and Saldana with the stages of data collection, data condensation, data presentation and drawing conclusions. The results showed that the influence of gadgets on the level of student learning, greatly decreased. Likewise, the level of spirituality of students during the Covid-19 pandemi, is very low. This is evidenced by the teachers who teach students at Madrasah every day, as well as student learning outcomes when doing daily tests and when doing assignments both at school and at home.

Abstrak: Berbicara tentang pendidikan tentu erat kaitannya dengan generasi peserta didik. Jika kita lihat kondisi pendidikan saat ini, terutama kualitas yang ada di dalam diri peserta didik, begitu sangat memprihatinkan. Handphone yang seharusnya digunakan untuk belajar di sekolahan, kini hanya sebatas untuk media bermain game. Tidak sedikit siswa yang mau membaca buku pelajaran, karena mereka sibuk membaca chatingan dari sang pacar. Bahkan tidak sedikit siswa yang pergi ke masjid untuk melaksanakan sholat dhuha maupun sholat fardhu karena mereka sibuk tik-tokan. Generasi peserta didik mulai banyak yang menghabiskan waktu dan umurnya di depan gadgetnya. Generasi yang Allah katakan di dalam Al-Qur'an sebagai khoiru ummah, kini menjadi hal yang jarang terlihat. Tujuan dari penelitian ini adalah untuk menginterpretasikan mengenai pengaruh gadget terhadap tingkat belajar dan spiritualitas siswa pada masa pandemi covid-19. Penelitian ini merupakan jenis penelitian kualitatif dengan pendekatan penelitian deskripsi kualitatif. Teknik pengumpulan data yang digunakan yaitu metode observasi, metode dokumentasi dan metode wawancara. Teknik analisis data yang digunakan ialah Miles, Huberman dan Saldana dengan tahapan koleksi data, kondensasi data, penyajian data dan penarikan kesimpulan. Hasil penelitian menunjukkan bahwa pengaruh gadget terhadap tingkat belajar siswa, sangat menurun. Begitupun juga tingkat spiritualitas siswa pada masa pandemi covid-19, sangat rendah. Hal itu dibuktikan dari guru yang setiap hari mengajar siswa-siswi di Madrasah, serta hasil belajar siswa pada saat mengerjakan ulangan harian maupun pada saat mengerjakan tugas baik di sekolah maupun di rumah. 


\section{A. Introduction}

The world today is in the era of the development of science and technology. One of the results of the development of science and technology is gadgets. Gadgets are electronic devices that function as communication tools and sources of information, for example smartphones, computers, laptops, tablets and others. The thing that distinguishes gadgets from other electronic devices is the element of novelty. Gadgets always update the system to the features it provides, thus making human life more practical and instant, one of which is on smartphones. Smartphones or what we often call HP are gadgets which in Indonesia itself are almost owned by everyone, both young and old (Marpaung, 2018). Even today, there are children who are given smartphone facilities by their parents. Features such as games and videos are interesting things that are liked by children, so parents give their children to play smartphones so they are not fussy (Hakim et al, 2021). This will make children addicted to playing gadgets. According to Hovart, addiction is not only found in substances but in certain activities that are carried out repeatedly and have a negative impact (Kasetyaningsih, 2015).

Gadgets in the world of education today are not only to find learning resources but also as a place to learn. The presence of the corona virus disease 2019 (Covid-19) outbreak which has hit 215 countries in the world, poses a challenge to the world of education. (Sadikin \& Hamidah, 2020). The Covid-19 pandemic that has changed the world to keep our distance because we are prohibited from doing activities in groups or are limited, which makes the world of education change the way of learning from face to face to online to reduce the risk of contracting Covid-19. An online learning system through a gadget in the form of a computer, laptop, or smartphone connected to an internet connection network (Daulay et al, 2020). Online learning allows educators and students to meet at the same time even in different places. So that online learning has more flexible learning time, where learning can be carried out anytime and anywhere (Chairulhaq et al, 2021). Covid-19 itself is a virus that attacks the respiratory tract characterized by coughing, runny nose, fever, shortness of breath and can even cause death. In line with the handling of Covid-19 by the government, there are currently several policies in the implementation of learning, namely learning that is carried out fully online or carried out online and face-to-face. Of course, when face-to-face, you must maintain the health protocol, namely washing your hands regularly with soap and clean water, wearing a mask and keeping a distance. (Amri et al, 2020).

Gadgets with complete features are not only for finding learning resources but can be used as learning media. Features such as games, YouTube, Instagram, quizzes, paint, photos, video editors, calculators, google search or often called "Mbah Google" and others are things that students enjoy (Rokhim, 2021). Online learning support applications such as zoom, google meet, classroom, padlet and others. While the application of learning materials, namely Ruang Guru, Quipper, Zenius, and others. However, seeing the fact that students who are in the environment around the researcher, they tend to install games such as Mobile Legend, PUBG, Free Fire and others. Social media such as Tik-tok, Instagram, 
Youtube, Twitter, Whatsapp and others can be used for friendship and adding friendship. Applications in gadgets can be a tool to develop self-potential, but can also be a tool to damage the personality of students (Ismail, 2018). Application features in gadgets such as videos, music, games, and other software can be used as entertainment (Siregar \& Wiza, 2021).

In essence, playing games and social media is not prohibited if in a standard portion. However, it was found that students who played games and social media forgot the time and place. For example, if the teacher is explaining the material, someone is busy scrolling Instagram, playing games and forgets to pray fardhu and others. Especially during the covid-19 pandemic where schools are online. So that teachers cannot supervise their students directly because they are blocked by different places and when they are doing faceto-face online many students close their cameras. This makes the teacher unable to determine whether the students actually follow the lesson or not. In addition, the use of gadgets can make children lazy to read books because they get short material from the internet, excessive use can make children lazy to do activities and interfere with learning concentration, and its impact on health can damage the eyes (Iqbal et al, 2020). Another impact of gadgets can make academic achievement decline, mental damage, and indifferent to the surrounding environment (Mauladina \& Giantara, 2020).

Gadgets can affect morals, religiosity, learning achievement, learning outcomes, interest/level of learning and spirituality. Gadgets have little or no influence on the mindset, behavior and actions. Parents are required to always accompany their children in playing gadgets so that children do not tend to like playing games or social media instead of studying and doing assignments. The level of student learning can be regarded as student learning interest. Interest in learning is the seriousness of students in focusing themselves by following learning well (Hudayana, 2018). So that the level of student learning can be said as how serious students are to take part in learning. Interest in learning is a sense of liking, interest, attention of students towards learning activities which is indicated by the behavior of students who are active and enthusiastic in learning. If students have a high interest in learning, then this will affect the ease with which students receive the material being studied. In addition, interest will reduce boredom in lessons (Kurniawan and Makin, 2021).

Students' interest in learning is shown by understanding the material or not being bored in participating in learning, this is also related to the impact if students have a good interest in learning so that the understanding of the material obtained reaches the spiritual side.Spirituality is not only found in places of worship and is not always synonymous with religion, although one of its sources is in religion. In Islam, kebatinan or spiritual is always directly related to the One God (Solehudin et al, 2021). According to Michael Levin in the writings of Galang et al, spiritual intelligence is a perspective that directs how to think towards the deepest nature of human life, namely self-servitude to the Most Holy and Allencompassing. The highest spiritual intelligence is seen if the individual reflects it in everyday life. In the form of an attitude that reflects his appreciation of deep wisdom and 
wisdom, with a holy path leading to the Creator. The process starts from the existence of spiritual awareness within the individual. Furthermore, this spiritual awareness encourages the emergence of spiritual understanding in children through the guidance of parents and their environment. So that with this understanding the child will be able to carry out a deep appreciation, which ultimately achieves spiritual meaning. This meaningfulness is the main source of the formation of spiritual intelligence. Spiritual intelligence allows individuals to better know what actions they will take which are good and right based on conscience, so that the function of spiritual intelligence is as a basis for considering ethical or not actions because its form itself is in the form of a moral attitude that is considered noble by the perpetrators of the action (Saputra et al, 2020). Spirituality can also be said as a way back to the path of religion, namely divinity and self-control. According to Danah Zohar in Moh. Sulaiaman et al. The characteristics of spiritual intelligence are recognizing the deepest motives, having high intelligence, being aware of oneself deeply, being able to take advantage of and overcoming difficulties, being able to stand tall or different from the crowd, reluctant to disturb or hurt, treat religion and death spiritually. Sulaiman et al (2018). Playing gadgets excessively to forget the time will affect spirituality. Because what we see will affect the behavior we will do. What we watch on gadgets and we like we tend to follow. Though we have to think about the impact of the behavior that we will do. As humans, we have an obligation to our Lord, namely to worship. Playing gadgets and forgetting the time can make us leave the obligation to worship (Syifa et al, 2019). For example, when praying when starting lessons, students do not focus on praying, but their minds are only playing with gadgets, or it could be when praying, they play games and don't even pray. In addition, the influence of gadgets on the spiritual side can be seen when viewing social media content that displays physical advantages. For example, seeing white people makes black people feel insecure so they want to change their bodies to be what they see them. Even though we as humans must accept and be grateful for what God has given us. Another effect of gadgets is when they are addicted and make someone irritable so they are easily influenced, for example to vilify the teachings of other religions or not respect other religions and even choose friends based on religion alone.

The impact of gadgets makes the author want to examine how the influence of using gadgets on the level of learning and spirituality of students during the covid-19 pandemic. Previously there have been studies on the same thing, but the difference in this study lies in the focus of the thing to be studied. Existing research includes research on 1.) The effect of gadgets on student interest in learning and discipline with the results that a. There is no positive effect of gadgets on discipline, $b$. There is no positive effect of gadgets on interest in learning, and c. There is no linear influence of gadgets on discipline and interest in learning (Hudayana, 2018). 2.) The effect of using gadgets on the emotional and moral development of students so that there are positive and negative impacts of gadgets. positive impact as a medium of information, communication, and learning media, while the negative impact is the emotional and moral impact. The forms of these emotions are self-doubt, feelings of shame, guilt and low self-esteem. Forms of moral disturbance are rude speaking, 
lying and so on (Hakim et al, 2021). 3.) The influence of gadgets on religiosity with negative and positive impacts, namely the negative impact of not caring and seeming indifferent to religious values, the positive impact is increasing religiosity through easy access to information supported by applications related to religion (Yuliana, 2018). And 4.) The effect of using gadgets on student achievement, the result is that the use of gadgets can affect student achievement (Kurniawan, 2020). While this research will examine the level of learning and spirituality of students. There are also differences in data and where the research was conducted.

\section{B. Method}

This type of research is qualitative research. The researcher uses this type of qualitative research because with this qualitative research the researcher can emphasize many aspects of one variable if possible as a problem that is studied more deeply and is closer to the data taken because the researcher follows the activities of the informants. While the research approach used is descriptive qualitative research in which this research provides an explanation or description of the object under study.

This study is intended to explain or interpret the effect of using gadgets on the level of learning and spirituality of students during the covid-19 pandemic. Thus, researchers can analyze and describe the facts about the effect of using gadgets on students' learning levels and spirituality.

MTS Negeri 2 Sleman which is located on Jalan Magelang Km.17, Ngosit, Margorejo, Tempel, Sleman, Yogyakarta is the location chosen by researchers to conduct research, because during the covid-19 pandemic researchers were carrying out field experience practices as well as teaching practices at MTS N 2 Sleman. Thus, researchers will find out as much as possible about the impact of the influence of gadgets on the level of learning and spirituality of students during the COVID-19 pandemic.

The population in this study were all teachers at MTS N 2 Sleman. While the sample in this study were teachers who were directly involved with students in teaching the subjects taught by each teacher.

The data used in this study can be classified into: (1) Primary data, namely data obtained directly from the object under study. Included in the primary data are the results of interviews with informants and documents from MTS N 2 Sleman. (2) Secondary data, namely data obtained from other than primary sources (second, third, etc.). Included in secondary data are supporting data from journals, books, magazines, newspapers, articles, internet, and social media related to the object of research.

In this study, the researcher used the validity of the data by testing the credibility and by means of triangulation. Triangulation is checking data from various sources in various ways and times. There are three types of triangulation in qualitative research, namely source triangulation, technical triangulation, and time triangulation. However, the researcher will only use two ways of triangulation, namely: 1) Triangulation of sources, to test the credibility of the data by checking the data obtained from several sources. 2) Triangulation 
Technique, to test credibility by checking data to the same source with different techniques. If this method produces different data, then a discussion is carried out with the relevant participants to obtain relevant and testable data (Sugiyono, 2017).

In this study, the data collection procedures carried out by the author are as follows: (1) Interview method. In this study, the authors tried to find information through interviews with related informants. In relation to qualitative research, the authors determine the informants who are expected to provide information in accordance with the research focus, namely the MTS N 2 Sleman teacher. This informant was selected based on certain criteria, including that the informant not only knows and can provide information, but also has lived it seriously as a result of his long involvement with the activity concerned. (2) Observation method. In this case, the researcher observes directly to the object of research with the aim of obtaining accurate data so that a discussion in this study will be achieved. Researchers pay attention to what is happening, listen to what is said, question information and study documents owned by informants (Sugiyono, 2017). (3) Documentation method, which is a technique of collecting data by collecting and analyzing documents in the form of writing or pictures. Documentation is done by reviewing documents related to research, including secondary sources.

The data obtained were analyzed using content analysis techniques. This technique includes three conditions, namely: objectivity, systematic approach, and generalization. (Bungin, 2013). The data analysis method used in this study is inductive in nature, namely the analysis based on the data obtained. To analyze the data, the researcher used a data analysis model from Miles, Huberman and Saldana which is known as the interactive model. Miles, Huberman and Saldana stated that this data analysis activity is an interconnected activity before, during, and after data collection in parallel form to build general insights called analysis (Sugiyono, 2017).

Data analysis activities with this interactive model include: 1) Data condensation, this process refers to the process of selecting data, focusing the data obtained, simplifying data, abstracting data, and transforming data that approximates the whole part of the document, and empirical materials. 2) Data presentation, which is a process of organizing, unifying, and summed up information. 3) Drawing conclusions, in this process, researchers research such as looking for understanding that does not have a pattern of noting the regularity of explanations, and causal paths in which the final stage concludes the entire data obtained.

\section{Result and Discussion}

\section{The Effect of Gadget on Students Learning Level}

From the results of interviews conducted by the author with teachers at MTS N 2 Sleman regarding the influence of gadgets on students' learning levels during the covid-19 pandemic, Mrs. Siti Marmiyati S.Pd who is often called Mrs. Marmi who is a teacher of Indonesian subjects at MTS N 2 Sleman said that while Mrs. Marmi was teaching in class, there were still students who did not listen to the teacher's explanation. In fact, when Mrs. 
Marmi gave assignments to students online using the Ge-School Application, there were still students who did not do the assignments at all.

The learning carried out at MTS N 2 Sleman is carried out using Blended Learning, where learning is carried out online and offline. Class VII, VIII, and IX students on Monday, Tuesday, Wednesday who enter Madrasah are odd absent. Then Thursday, Friday, Saturday leaving for Madrasah is an even absence. Furthermore, Monday, Tuesday, Wednesday those who enter Madrasah are even absent. Then Thursday, Friday, Saturday leaving for Madrasah is an odd absence. And so on. Thus, students who are at home do not mean that there is no teaching and learning. Teachers continue to monitor student attendance and always supervise students during learning through an application called Ge-School.

However, in reality, students who are at home, when there is an Indonesian language lesson, there are still students who are not present and do not participate in online learning. Mrs. Marmi, who is a class IX teacher of Indonesian, said honestly that Mrs. Marmi is not willing to call every day, morning, afternoon, evening or night to students who never do assignments. Mrs. Marmi is not ashamed of all that. There are even students who dare to speak impolitely, but Mrs. Marmi considers it a normal thing and never holds a grudge against her students. Because for Mrs. Marmi, education is number one.

Andre is one of the class IX students who was contacted by Mrs. Marmi, the Indonesian language teacher. Even though her calls were repeatedly rejected, Mrs. Marmi really cares and cares for her students. Mrs. Marmi doesn't want the students taught in her class to get bad grades. Mrs. Marmi doesn't want the students of MTS N 2 Sleman not to gain knowledge, let alone Islamic knowledge. Because after all, the students of MTS N 2 Sleman are already considered like their own children. Bu Marmi feels that the salary provided by the State is just a bonus. Because in truth, when we teach and our intentions are lillahi ta'ala, whatever activities we do while in the world, it will be rewarded, and as a weight for Windom the scales of righteous deeds when the Day of Judgment comes.

As an educator, Mrs. Marmi realizes that in teaching material to students, she does not just provide material. However, Mrs. Marmi always gives advice to her students. The advice given by Mrs. Marmi is nothing but about the Islamic aqidah. Don't forget, before the lesson starts, Mrs. Marmi always tells her students to pray first. After that, Mrs. Marmi gave advice in the form of Islamic religious knowledge, so that students can gain enlightenment before learning takes place in class. Then after praying and giving advice and advice, Mrs. Marmi gave the subject matter that would be studied in class.

However, because in Madrasahs there are no rules for asking students to collect cellphones during learning, this causes some students to not pay attention to the teacher's explanation. In fact, when the teacher gives assignments to students in class, there are still students who are even busy playing Mobile Legend, playing Zombies, and so on.

That is the reason why the gadget is very influential on the level of student learning. Books that should be read to be studied and practiced, are now only limited to display and decoration at home. Not a few students want to read textbooks, because they are busy playing gadgets. Not a few students who want to study to prepare for the Final Semester 
Exam, because they are busy chatting. In fact, every time you want to sleep and wake up, all you think about is gadgets, gadgets, and gadgets.

Mrs. Wahyuningsih S.Pd who is a teacher and homeroom teacher for class IX B at Madrasah Tsanawiyah Negeri 2 Sleman also said that during the covid-19 pandemic, students of MTS N 2 Sleman were very minimal in their studies, so the results of the students' daily tests were available. who get a bad score below the KKM. Not a few of the students who get good grades above the KKM. Moreover, if students already hold their gadgets, the textbooks do not want to be read, let alone touched. Therefore, student learning outcomes also decreased. Finally, students no longer have the enthusiasm to learn.

However, Mrs. Wahyu as the homeroom teacher for class IX B always gives motivation and advice to her students. Start from before learning begins. Bu Wahyu always tells students to use their cellphones for useful things, such as for learning when the teacher gives assignments online, or when there are questions from the teacher then students are asked to look for answers on the internet, and so on. So that way, it will minimize and reduce students in using gadgets for things that are less useful.

Mrs. Wahyu, who is one of the teachers at MTS N 2 Sleman, once gave daily test questions to her students in offline classes. However, among the class IX B students, there were only 3 students who got good grades, and the other students got scores below the KKM. However, when the teacher gives assignments online at home through the Ge-School Application, students who work on questions at home, most of the students do not do daily test questions. Finally, students who did not do the test were asked to come to the Madrasa to do the test offline.

Even in class. Mrs. Wahyu has explained the material used for daily tests. However, I also have self-students who don't pay attention to the teacher's explanation because the students are busy with their gadgets so that it has an impact on student learning outcomes which decrease. Therefore, not a few of the students want to listen to the teacher's welding, because they are busy in front of their cellphones. Not even a few of the students are active in answering questions from the teacher because they are busy chatting with their gadgets.

\section{The Effect of Gadgets on Students Spirituality Level}

When learning Indonesian, Mrs. Marmi tried to ask the students of MTS N 2 Sleman. For students who raise their hands, will be given money Rp. 50,000.00. Then Mrs. Marmi asked her students, "Please answer honestly, who in this class was doing the Fajr prayer?" None of the students raised their hands. Astaghfirullah things adzhim. Is it a generation of agents of change? Is that the generation that Allah says is the khoiru ummah? Islamic religious knowledge given 2 hours of lessons in one week, is that enough to shape the character of students who have noble character? Not. Religious lessons should be longer than other lessons. Because religious education is very important to be taught to every student according to their respective beliefs. For this reason, Islamic religious knowledge teaches students to be kind, respectful and obedient to teachers. However, currently religion 
is only underestimated by some students, because it is an easy lesson. In fact, if we study more broadly, religious lessons are very broad and we must even be obliged to study them.

The influence of gadgets is not only about worship, but also affects the morals of students. Lately, students' morale is low because they dare to yell at the teacher, dare to fight and even kill him. It is also one of the consequences of gadget addiction. How can this happen in our own country, Indonesia? It really tarnishes the good name of education in Indonesia. Students who are supposed to be the next generation of leaders of Islamic civilization, but now many are influenced by gadgets. Why did it happen? Isn't that a big problem for Indonesia? Or is it something that we take for granted? In fact, in Islam, we as students are taught to respect each other who are older than us, especially teachers. The teacher who has given us knowledge, who has a very noble position in the eyes of Allah SWT. We should respect. We are forbidden to speak harshly let alone raise our voices to the teacher. We are also prohibited from talking when the teacher is transferring knowledge to us. Students do that, because gadgets have poisoned their minds, so religion is no longer applied in everyday life. Religious knowledge is only limited to knowledge, but is not practiced or applied in everyday life. For this reason, students' morals and morals gradually become low.

Even though Mrs. Marmi already has a family, Mrs. Marmi always puts students at MTS N 2 Sleman first. Every time Mrs. Marmi would pick up her young son from kindergarten, she always put the students at MTS N 2 Sleman first, and she couldn't bear to leave her students. Because, students are the generation of civilization. The generation of khoiru ummah as mentioned in the Qur'an Surah Ali-Imran verse 110 which means: "You are the best ummah who was born for humans because you call on what is right and forbid what is evil". The generation that will change the fate of the Indonesian people for the better. The generation that will print changes in Islamic civilization.

During the daily test, Mrs. Marmi as an Indonesian teacher at MTS N 2 Sleman gave assignments to students to read a text, then students were asked to answer questions from the text that had been read, including what the topic was from the reading text, where was the setting the event, and what is the message or message that can be obtained from the results of the reading text. From this question, there are still students whose scores are still below the KKM, which is 75. Students who get good scores above the KKM can only be counted on their fingers.

Not infrequently teachers like Mrs. Marmi are willing to go in the middle of the night just to call their students asking if their assignments have been done or not. Not a few teachers today are willing to give honest grades as they are because they do not want their students to be given grades below the KKM. Not even a few teachers who instill Islamic religious values on the sidelines of teaching because they focus on the administration of teachers who have to meet deadlines every day. Therefore, students who should have been instilled in the Islamic creed from an early age from their parents, are now confined to schools. 
Parents who should be the number one educators at home, can only rely on schools as places to gain knowledge. In fact, it is parents who should give knowledge to their children. Teachers in schools are only as intermediaries and guides in teaching and learning in schools. However, the people who play the main role in educating their sons and daughters are none other than parents.

Mrs. Wahyuningsih S.Pd, who is often called Mrs. Wahyu, said that the spirituality level of students during the COVID-19 pandemic was somewhat less elevated and tended to be low. Because, from the observations and interviews of teachers with students, only a few students are willing to carry out fardhu prayers in an orderly manner. In addition, only a few of the students are willing to read the Qur'an at home. Not many students want to do the sunnah prayer at school, because they are busy playing with their gadgets. Therefore, gadgets have a huge impact on the level of intelligence of students in learning and the level of spirituality of students.

\section{Conclusion}

Based on the results of the research and discussion that the authors have described above, it can be concluded that the effect of using gadgets on student learning levels at MTS $\mathrm{N} 2$ Sleman is greatly decreased. This can be seen from student learning outcomes when doing daily tests and when doing assignments both at school and at home.

Meanwhile, the effect of using gadgets on students' spirituality levels during the COVID-19 pandemic is very low. This is evidenced by the teacher who teaches students at Madrasah every day, and the teacher tries to ask questions and give gifts to students who perform the Fajr prayer, but none of the students raise their hand. Thus, the use of gadgets is very influential on the level of student worship and the level of student learning during the covid-19 pandemic.

\section{Acknowledgment}

This research could not be separated from the help and motivation of various parties. The author would like to thank:

1. Prof. Fathul Wahid, S.T., M.Sc., Ph.D as Chancellor of the Indonesian Islamic University.

2. All lecturers of the Islamic University of Indonesia who have shared knowledge with the author during the study process.

3. All staff and employees of the Islamic University of Indonesia who have helped a lot in the preparation of this research.

4. The head of Madrasah, teachers, and employees of MTS N 2 Sleman who have given permission and opportunity to the author to conduct this research.

5. Teachers of MTS N 2 Sleman who are willing to be informants in this study.

6. All friends who cannot be mentioned one by one because of their many, who have become entertainers, advisers, and are willing to be a place to complain.

7. Parents and extended family who cannot be mentioned one by one, thank you for your prayers and support in writing this research. 
8. All parties who have helped so that this research can be completed properly.

\section{References}

Amri, M. I. A. U., Bahtiar, R. S., \& Pratiwi, D. E. (2020). Dampak Penggunaan Gadget terhadap Kemampuan Interaksi Anak Sekolah Dasar pada Situasi Pandemi Covid-19. Trapsilia: jurnal Pendidikan dasar, 2(2), 14-23.

Bungin, B. (2013). Analisis Data Penelitian Kualitatif Pemahaman Filosofis dan Metodologis ke Arah Penguasaan Model Aplikasi. Yogyakarta: Raja Grafindo Persada.

Daulay, R. S., Pulungan, H., Noviana, A., \& Hurhaliza, S. (2020). Manfaat Teknologi Smartphone dalam kegiatan Pembelajaran Pendidikan Islam Di Masa Pandemi Corona-19. Al-Ulum: Jurnal Pendidikan Islam, 1(1).

Hakim, A. R., Zohrani, Z., Yazid, M., Kudsiah, M., \& Alwi, M. (2021). Pengaruh Penggunaan Gadget Terhadap Perkembangan Emosional dan Akhlak Peserta Didik. Jurnal DIDIKA: Wahana Ilmiah Pendidikan Dasar, 7(1), 149-162.Hudayana, A. (2018). Pengaruh Gadget Terhadap Sikap Disiplin dan Minat Belajar Peserta Didik. Research and Development. Journal of Education, 4(2), pp. 91-92

Ismail. (2018). Peran Guru Pendidikan Agama Islam Dalam Mengantisipasi Dampak Penggunaan Media Sosial Bagi Siswa Sekolah Menengah Pertama. IQRO: Journal of Islamic Education, 1 (1), pp.106

Kasetyaningsih, S.W. (2015). Pengaruh Aplikasi Islami di Gadget Terhadap Sisi Religiousitas Mahasiswa. Jurnal Duta.com, 9(2), pp. 22

Kurniawati, D. (2020).Pengaruh Penggunaan Gadget Terhadap Prestasi Siswa. Edukatif: Jurnal Ilmu Pendidikan, 2(1), pp 83

Kurniawan, D. E. (2021). Pengaruh Metode Pembelajaran Daring Terhadap Minat Belajar Mahasiswa Di Masa Pandemi Covid-19. Jurnal Education and Development, 9(2), 47-51.

Marpaung, J. (2018). Pengaruh Penggunaan Gadget Dalam Kehidupan (The Effect Of Use Of Gadget In Life). Jurnal Kopasta, 5(2), pp. 56-57

Mauladina, I., \& Giantara, F. (2020). Kreativitas Siswa Dalam Penggunaan Gadget Pada Pembelajaran PAI Di Masa Covid-19. Al-Mutharahah: Jurnal Penelitian Dan Kajian Sosial Keagamaan, 17(2), 218-226.

Rokhim M.A. (2021). Peranan Media Gadget dalam Implementasi Kebijakan Pembelajaran PAI di Masa Pandemi Covid-19. Ar-Risalah: Jurnal Media Keislaman, Pendidikan, dan Hukum Islam, 19(1), pp. 100

Sadikin, A., \& Hamidah, A. (2020). Pembelajaran Daring Di Tengah Wabah Covid-19 (Online Learning in the Middle of the Covid-19 Pandemic). Biodik, 6(2), 214-224. 
Saputra, G. W., Rivai, M. A., Su' udah, M., Wulandari, S. L. G., Dewi, T. R., \& Fitroh, F. (2017). Pengaruh Teknologi Informasi Terhadap Kecerdasan (intelektual, spiritual, emosional dan sosial) studi kasus: anak-anak. Studia Informatika: Jurnal Sistem Informasi, 10(2).

Siregar, N. H., \& Wiza, R. (2021). Pengaruh Penggunaan Gadget terhadap Akhlak Remaja. An-Nuha, 1(2), 152-158.

Solehudin, A., Prasetiya, B., \& Halili, H. R. (2021). Pengaruh Penggunaan Gadget dan Pola Asuh Islami terhadap Mental Spiritual Siswa. Edumaspul: Jurnal Pendidikan, 5(2), 544553.

Sugiyono. (2017). Metode Penelitian Kuantitatif, Kualitatif, dan RED. Bandung: Alfabeta.

Sulaiman, M., Al Hamdani, M. D., \& Aziz, A. (2018). Emotional Spiritual Quotient (Esq) Dalam Pembelajaran Pendidikan Agama Islam Kurikulum 2013. Jurnal Penelitian Pendidikan Islam,[SL], 6(1), 77-110.

Syifa, L., Setianingsih, E. S., \& Sulianto, J. (2019). Dampak Penggunaan Gadget terhadap Perkembangan Psikologi pada Anak Sekolah Dasar. Jurnal Ilmiah Sekolah Dasar, 3(4), 527-533.

Amri, M. I. A. U., Bahtiar, R. S., \& Pratiwi, D. E. (2020). Dampak Penggunaan Gadget terhadap Kemampuan Interaksi Anak Sekolah Dasar pada Situasi Pandemi Covid-19. Trapsilia: jurnal Pendidikan dasar, 2(2), 14-23.

Yuliana, Y.(2018).Pengaruh Gadget (Smartphone) Bagi Kehidupan Keagamaan Mahasiswa (Studi Kasus Pada Sekolah Tinggi Manajemen dan Ilmu Komputer Prabumulih Sumatera Selatan). Jurnal Pendidikan Islam Rabbani, (2)2, pp 397. 